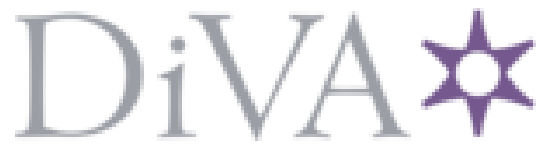

http://www.diva-portal.org

Preprint

This is the submitted version of a paper published in Biblical Interpretation.

Citation for the original published paper (version of record):

Berber Neutel, K., Bjelland Kartzow, M. (2020)

Neighbours Near and Far: How a Biblical Figure is Used in Recent European AntiMigration Politics

Biblical Interpretation

https://doi.org/10.1163/15685152-2020003

Access to the published version may require subscription.

N.B. When citing this work, cite the original published paper.

Permanent link to this version:

http://urn.kb.se/resolve?urn=urn:nbn:se:umu:diva-18296o 


\section{Neighbours Near and Far: How a Biblical Figure is Used in Recent European Anti-Migration}

\section{Politics}

\section{Abstract}

References to the Bible in European politics rarely are the subject of research by biblical scholars. Claims about Christianity and about themes and stories from the Bible, which have made a remarkable appearance in political discourse recently, especially in discussions of migration, have therefore gone unnoticed in our discipline. This paper wants to put this topic on the map by exploring three cases, from the Netherlands, Norway, and Germany, where politicians make an argument against accepting migrants, by appealing to neighbourly love and the story of the Good Samaritan (Luke 10:25-37). We ask whether the Bible appears here in its 'liberal' form, which scholars have shown to be a prevalent form of the Bible in US and UK politics, or whether we are seeing the development of a different political Bible.

Keywords

Neighbour, politics, migration, Good Samaritan, Luke, parable

\section{Introduction}

Recent political discourse on the topic of migration has seen a remarkable return of the idea that Europe has a specifically Christian identity. ${ }^{1}$ From Norway to Hungary, and from Italy to the Netherlands, political parties that run on a platform of hostility towards migration, as well as Islam,

\footnotetext{
${ }^{1}$ The terminology used in connection with people who move within and between countries is a fraught issue, since many terms carry implicit notions of legitimacy. Here we use 'migration' and 'migrant' as broad terms that aim to avoid such connotations. See also Paola Pace and Kristi Severance, 'Migration terminology matters', Forced Migration Review 51 (2016), pp. 69-70. The UN's International Organization for Migration provides a list of key terms at https://www.iom.int/key-migration-terms.
} 
assert that they are defending Europe's Christian heritage and values. ${ }^{2}$ Along with these appeals to Christianity comes a renewed political application of the Bible, a phenomenon which so far seems to have escaped biblical scholars. This article will offer a first exploration of such political references to the Bible, by analysing three recent cases from the Netherlands, Norway, and Germany, all focussed on the same biblical theme. In these three cases, politicians refer to the Christian notion of neighbourly love, and the parable of the Good Samaritan, to argue against accepting migrants into their countries.

Even though the politicians in focus here do not belong to traditional Christian parties, they and the parties they represent, the Forum voor Democratie (Forum for Democracy, FvD), the Fremskrittspartiet (Progress party, Frp) and the Alternative für Deutschland (Alternative for Germany, AfD) have all made claims to stand for Christian values and tradition, and have criticised others who identify as Christian for failing to do so. AfD leader Alice Weidel, for example, has stated that her party is in fact the only Christian party in Germany. ${ }^{3}$

Such rhetoric represents a shift in political discourse in northern European countries, which have long been seen as distinctly secular. ${ }^{4}$ Rather than oppose immigration and Islam by referring primarily to secular values, or by rejecting religion altogether, as might have been expected, politicians instead choose to portray the cultural identity of Europe as essentially Christian, and therefore incompatible

\footnotetext{
2 Political scientists have taken a strong interest in this phenomenon, see, e.g., Daniel Nilsson DeHanas and Marat Shterin, 'Religion and the Rise of Populism', Religion, State \& Society 46/3 (2018), pp. 177-185; Nadia Marzouki, Duncan McDonnell and Olivier Roy (eds.), Saving the People: How Populists Hijack Religion (London: Hurst\& Company, 2016).

${ }^{3}$ See https://www.t-online.de/nachrichten/deutschland/parteien/id 82937780/alice-weidel-sieht-afd-als-dieeinzige-christliche-partei-.html. Norwegian politician Sylvi Listhaug has criticized the leader of the Christian Democratic Party for failing to defend Christian values which, she argued, are under pressure due to Muslim migrants (Sylvi Listhaug, Der andre tier (Oslo: Kagge Forlag, 2018), pp. 143-154. Thierry Baudet has suggested that Christianity has a role to play in reinventing the values necessary to combat 'Europe's identity crisis' https://cip.nl/60959-thierry-baudet-pleit-voor-herwaardering-christendom.

${ }^{4}$ In his study of the role of religion in nationalisms in Europe, Philip W. Barker focusses on Greece, Ireland and Poland, as countries where religion can still be presumed to play such a role. This in contrast to European countries such as Germany, the Netherlands and Norway, which are briefly discussed by Barker under the heading 'secular nationalism'. For the Netherlands, Barker suggests that while the connection between religion and nationalism has been dormant for centuries, if the growth of Muslim populations is seen as threatening, 'it is likely that religion could reenter the debate in the Netherlands'. He notes a similar possibility in the case of Germany, though not for Scandinavian countries. (Religious Nationalism in Modern Europe: If God Be for Us (Abingdon: Routledge, 2009), pp. 161-165, 164).
} 
with, and threatened by, Islam. The 'Muslimisation' of the migrant thus seems to go hand in hand with an increased 'Christianisation' of European self-understanding. ${ }^{5}$ These three cases then allow us to examine this phenomenon of 'Christianisation' in more detail and offer a way to compare the discourse in three European countries. They do not, of course, enable any generalisations, but by selecting these examples of prominent politicians who all support restricting migration with reference to neighbourly love, we can get an idea of the ways in which biblical themes and figures are used in public political discourse today.

Our goal is to see what these cases tell us about the ways in which biblical stories and values are interpreted, how they can be used to support political positions, and in particular, how the neighbour is seen as meaningful in this new political context. So far, the recent political Christianisation has been studied primarily by political scientists, among whom the current consensus appears to be that appeals to Christianity are predominantly rhetorical and instrumental and even constitute an 'exploitation' of religion. ${ }^{6}$ Scholars base this assessment on a rather normative distinction between 'Christendom', which is considered to be focussed on 'belonging', and concerned primarily with identity and territory, and 'Christianity' which is understood as actual Christian faith. This scholarship therefore tends to see Christian churches and established Christian political parties as more legitimate representatives of Christianity than the political actors who oppose migration and Islam. This article aims to avoid such determinations of what counts as legitimate interpretation or application of Christian values and biblical themes. Instead, we take the concept of the 'liberal Bible' as a point of comparison, to establish whether these appeals to the Bible are similar to, or different from, the way the Bible is used in contemporary politics elsewhere. We will first discuss this concept and its

\footnotetext{
${ }^{5}$ W. Schiffauer, 'Der unheimliche Muslim - Staatsbürgerschaft und zivilgesellschaftliche Ängste', in L. Tezcan and M. Wohlrab-Sahr (eds.), Konfliktfeld Islam in Europa (Baden-Baden: Nomos, 2017), pp. 111-134.

${ }^{6}$ Such views are expressed, for example, in Daniel Coyne, 'Populism and Religion: A Conclusion', LSE Religion and Global Society Blog 2019; DeHanas and Marat Shterin, 'Religion and the Rise of Populism'; Marzouki, McDonnell and Roy, Saving the People; Nadia Marzouki and Duncan McDonnell, 'Us' and the 'Other': How Populists Continue to Hijack Religion', LSE Religion and Global Society Blog 2018; Olivier Roy, "A Kitsch Christianity': Populists Gather Support While Traditional Religiosity Declines', LSE Religion and Global Society Blog 2018; Olivier Roy, L'Europe est-elle chrétienne? (Le Seuil, 2019).
} 
relevance, and then briefly reflect on interpretations of neighbourly love and the parable of the Good Samaritan, before turning to a discussion of the three cases central to this article.

\section{Politics and the Liberal Bible}

The field of reception studies is of increasing importance within the discipline of Biblical Studies overall. However, the role of the Bible in political contexts tends to be a somewhat neglected topic, especially when it comes to European countries. Some even appear to assume that there is no such role. Masiiwa Ragies Gunda and Joachim Kügler, editors of the 2012 volume The Bible and Politics in Africa, explain in their introduction to this work that while they originally intended to focus on both Africa and Europe, they ended up having to leave out the latter continent due to a lack of interest 'from the European side'. ${ }^{7}$ Many European biblical scholars, they note, assume that 'the era of Bibleinfluenced politics is behind them'. According to these scholars, 'the Bible has no relevant and valid function in contemporary political discourse'.$^{8}$ Although it may be used less prominently than in the African political discourses analysed in Gunda and Kügler's study, we argue the Bible is not left behind in Europe; it rather appears in new, and perhaps unexpected, ways.

As Yvonne Sherwood has shown, the Bible is very much a concern in recent debates about fundamental political issues such as liberalism, rights and justice. ${ }^{9}$ Those who hold a positive view of the Bible tend to present it as in basic agreement with liberal democracy, with human rights, freedom of the individual and separation of church and state. This understanding of the Bible, termed by Sherwood the 'Liberal Bible', appears as a 'vague container for morality (the religious translated into practical, universal and utilitarian terms), the civil, the democratic and the humane'.${ }^{10}$ Constructed in

\footnotetext{
${ }^{7}$ Masiiwa Ragies Gunda and Joachim Kügler, The Bible and Politics in Africa (Bamberg: University of Bamberg Press, 2012), p. 9.

${ }^{8}$ Gunda and Kügler The Bible and Politics in Africa, p. 10.

9 Yvonne Sherwood, Biblical Blaspheming: Trials of the Sacred for a Secular Age (Cambridge: Cambridge University Press, 2012), pp. 303-310, see also Yvonne Sherwood, 'Bush's Bible as a Liberal Bible (Strange Though That Might Seem)', Postscripts: The Journal of Sacred Texts and Contemporary Worlds 2 (2006), pp. 47-58; Yvonne Sherwood, 'The God of Abraham and Exceptional States, or the Early Modern Rise of the Whig/Liberal Bible', Journal of the American Academy of Religion 76 (2008), pp.312-343.

${ }^{10}$ Sherwood, Biblical Blaspheming, p. 4.
} 
this way, the Bible can endorse actions against what is seen as its opposite: tyranny, terror, and the absence of democracy. ${ }^{11}$ Even though this Liberal Bible has its roots in sixteenth and seventeenthcentury Europe, as Sherwood demonstrates, it appears as self-evident and timeless to those who refer to the Bible today, not only among those who identify as Christian, but also among theorists of secularisation, democracy, and human rights more broadly. ${ }^{12}$

\begin{abstract}
Whatever their theological-political orientation, all current, creative, appeals to the theological-political promise of the Bible and Christianity take place within the legacy of the Liberal Bible. They dance their giddy theological-poetic acrobatics above the safety net of the Liberal Bible. They can take such risks because they can safely invoke the Bible as the source of a few axiomatic political-theological principles, rather than (...) the source of a detailed textual agenda for the state. ${ }^{13}$
\end{abstract}

The concept of the Liberal Bible has so far been applied to political discourse in the United States, England and New Zealand. ${ }^{14}$ Our goal in this article is to see whether the three recent cases of political appeals to the neighbour in the Netherlands, Norway, and Germany also rely on the safety net of the liberal Bible for their flexible exegesis, or rather construe the Bible in a different way. Do they take it as a vague container for morality, which can be used against those who are taken to stand for its opposite - a lack of democracy, rejection of rights and freedoms - or do they engage in more detailed readings to support more specific political policies?

\footnotetext{
${ }^{11}$ James G. Crossley, 'God and the State: The Bible and David Cameron's Authority', in: Jim West and James G. Crossley (eds.), History, Politics and the Bible: From the Iron Age to the Media Age (London: Bloomsbury, 2017), pp. 146-162.

${ }^{12}$ Sherwood, Biblical Blaspheming, pp. 310-332.

${ }^{13}$ Sherwood refers here to the work of scholars such as Francis Fukuyama, Peter Berger, and Marcel Gauchet (Sherwood, Biblical Blaspheming, p. 330).

${ }^{14}$ For the US, see Sherwood, 'Bush's Bible'; for England, see James Crossley, Harnessing Chaos: The Bible in English Political Discourse since 1968 (London: Bloomsbury, 2014), who explains specifically 'why English' political discourse on pages 4-8; for New Zealand, see Robert J. Myles, 'Winston Peters "Puts His Hand to the Plow" The Bible in New Zealand Political Discourse', Journal of the Bible and its Reception 3/1 (2016), pp. 135153.
} 


\section{The Neighbour in context}

\subsection{Interpreting the Good Samaritan}

At this point, it might be expected that we would turn to the Bible, to analyse the texts that form the basis for any references to neighbourly love and the Samaritan. Yet in studying biblical reception, it is important to think about what exactly is received. Is it indeed a particular text, and if so which form, which translation or retelling? Or is it a remembered story, a general theme, or a distant echo of a children's Bible? In the case of political reception, it is often difficult to know what exactly lies behind references to the Bible and to what extent interpreters are aware that they are constructing a particular reception of a pre-given entity, rather than employing a cultural or linguistic trope. ${ }^{15}$

This applies all the more when it comes to neighbourly love, and the figure of the Good Samaritan, which can easily be taken as self-evident elements of Christian tradition, without requiring much regard or awareness of Jewish origins or specific biblical backgrounds. To start a discussion of the political reception of neighbourly love and the Good Samaritan with a detailed discussion of the text of Luke 10,29-37, and of the neighbour in the Hebrew Bible, would therefore be constructing an artificial Vorlage which may not actually be part of the process of reception at all. It makes more sense instead to reflect on the figure of neighbour, particularly in the shape of the Samaritan, in previous interpretations and attempt to place the receptions that occur in our political cases in this broader context. We will first briefly discuss understandings of the Good Samaritan in general, and then turn more specifically to the political context.

To write the reception history of the parable of the Good Samaritan would be almost an impossible task and one that far exceeds the scope of this paper. Suffice it to say here that while a range of readings can be found, one particular line of thought can be identified as dominant in current interpretations: the Good Samaritan is a helpful stranger, someone who comes to another person's

\footnotetext{
15 This is part of what some scholars refer to as the 'Cultural Bible', the Bible as a 'classic', a cultural and pedagogical resource, closely associated with language and heritage (Crossley, Harnessing Chaos, pp. 10-12).
} 
aid without being expected to do so. ${ }^{16}$ According to many biblical commentaries, the Samaritans were viewed with hostility by Jews at the time. ${ }^{17}$ Therefore, the meaning of the parable is often taken to be that those who belong to your own group may let you down and pass by on the other side of the road when you need them most. Loving one's neighbour then means following the unexpected example of the Samaritan, to show neighbourly love beyond your own community or those who are familiar to you. As Luke Timothy Johnson argues, 'The parable itself is intended to provoke (...) It is the hated enemy who is the hero with a human heart'. ${ }^{18}$

While this reading may be familiar, it is important to point out that it is not accepted by all scholars today, nor was it the dominant reading at all times. Louise Schottroff, for example, argues that to interpret the parable 'in terms of generalized love of humanity of love of enemies misses the point of the text in a significant way'. The ethnic relationship between the Samaritan and the victim is not made explicit; we do not hear whether the latter was a Jew. According to Schottroff, the story is not about ideas of love, but rather about love as a deed. The Samaritan imitates God, who always stands on the side of those who need love. ${ }^{19}$

While the 'ethical' meaning of the story is taken for granted in many commentaries today, Riemer Roukema has shown that in ancient Christianity, the parable was often interpreted allegorically. ${ }^{20}$ This reading in fact continued well into the $20^{\text {th }}$ century, since Karl Barth, among others, understood the

\footnotetext{
${ }^{16}$ This is the common understanding of the term today, as evidenced for example in dictionaries (e.g., 'a person who helps someone they do not know who is in trouble' https://www.macmillandictionary.com/ dictionary/british/good-samaritan) and news media headlines such as 'Woman rescued by good Samaritan from knifepoint attack' (https://www.bbc.com/news/uk-england-dorset-51503024), as well as in law (see, e.g., John T. Pardun, 'Good Samaritan Laws: A Global Perspective', Loyola of Los Angeles International \& Comparative Law Review 591 (1998), pp. 591-613).

${ }^{17}$ See, e.g., John T. Carroll, Luke: A Commentary (Louisville: Westminster John Knox Press, 2012), pp. 245-246; ; Joel B. Green, The Gospel of Luke (NICNT; Grand Rapids: William B. Eerdmans Publishing Company), pp. 404405, 431; Luke Timothy Johnson, The Gospel of Luke (Sacra Pagina Series vol. 3; Collegeville, Minnesota: The Liturgical Press, 1991), p. 162; Louise Schottroff, The Parables of Jesus (Minneapolis: Fortress Press, 2006), p. 135.

18 Johnson, The Gospel of Luke, p. 175.

19 Schottroff, The Parables of Jesus, p. 134.

${ }^{20}$ Riemer Roukema, 'The Good Samaritan in Ancient Christianity', Vigiliae Christianae 58 (2004), pp 56-74.
} 
Samaritan to be a representation of Christ. ${ }^{21}$ Irenaeus, Origen, Augustine and other early readers had more elaborate allegorical interpretations, and did not necessarily see the parable as a story about the duty of humans to love outsiders. Irenaeus, for example, not only interprets the Good Samaritan as Christ, but also sees the wounded man as a representation of humanity, the innkeeper as a personification of the Spirit, and the two denarii paid to the innkeeper by the Good Samaritan as signifying 'the Father and the Son' ${ }^{22}$ According to Roukema, the most profound intention of the text for those who read it allegorically, is to show how Christ offers salvation to humankind. ${ }^{23}$ The fact that the Good Samaritan has become a byword for a helpful stranger should thus not prevent us from recognising that a range of meanings have been and continue to be attributed to the parable.

\subsection{The Political Neighbour}

Focussing more narrowly on the realm of politics, the Samaritan and neighbourly love have also been understood in a range of ways in this specific context. Nick Spencer's study The Political Samaritan, which analyses political discourse in the UK and US, examines how the motif has been interpreted and used, and shows that, in spite of decreasing membership of churches and a general lack of biblical knowledge in the contemporary UK, this theme from the Bible has survived in public discourse. ${ }^{24} \mathrm{He}$ finds that the Good Samaritan and neighbourly love are mentioned with a variety of applications: 'It is a parable that, in spite of its extremely demanding ethical message - one might even say its preachy tone - remains astonishingly popular; a parable that, despite its rather disputed meaning, is seized -

\footnotetext{
${ }^{21}$ Roukema, 'The Good Samaritan', p. 57, note 4, referring to Karl Barth, Die kirchliche Dogmatik I,2 (Zürich: Zollikon, 1945), p. 462; Die kirchliche Dogmatik III,2 (1948); Die kirchliche Dogmatik IV,1 (1953), among other authors.

${ }^{22}$ Adversus Haereses III,17,3, see Roukema, 'The Good Samaritan', p. 59, also David B. Gowler, The Parables After Jesus: Their Imaginative Receptions Across Two Millennia (Grand Rapids: Baker Academic, 2017), pp. 19, 42-43. Other examples occur in James Crossley, Cults, Martyrs and Good Samaritans: Religion in Contemporary Political Discourse (London: Pluto Press, 2018).

${ }^{23}$ Roukema, 'The Good Samaritan', p. 74.

${ }^{24}$ Nick Spencer, The Political Samaritan: How Power Hijacked a Parable (London, Oxford: Bloomsbury, 2017). Spencer cites YouGov research from 2015, according to which $70 \%$ of respondents had heard of the parable (Spencer, The Political Samaritan, p. 45).
} 
one might even say hijacked - by politicians across the spectrum for a bewildering range of purposes'..$^{25}$

In reviewing the history of reception, Spencer gives some striking examples: abolitionists used the parable and the idea of neighbourly love to argue against slavery and the slave trade. ${ }^{26}$ Martin Luther King, in his last speech before he was killed, employed the parable to address the political and social climate in the US, and saw the Samaritan as 'a man of another race' who could project 'the "I" into the "thou"'. ${ }^{27}$

Spencer's work shows that the theme is found across the British political spectrum. Margaret Thatcher famously made reference to the parable in several of her speeches, arguing that 'even the Good Samaritan had to have money to help, otherwise he too would have had to pass by on the other side' ${ }^{28}$ The idea of 'not passing by on the other side' is used frequently by Labour politicians as well, including Tony Blair, Gordon Brown, and Jeremy Corbyn. ${ }^{29}$ Given its moral appeal and its broad applicability, this expression seems to fit well with the concept of the Liberal Bible. It stands for a way of acting that is ethical and civil, whatever the issue or the required policy may be.

The phrase also plays a role in recent discussions of migration. In 2015, Nichola Sturgeon, First Minister of Scotland, criticised the UK government's 'walk by on the other side' approach. ${ }^{30}$ A year later, Labour MP Yvette Cooper stated that 'It is no good telling children the parable of the Good Samaritan if all we in this House are prepared to do is walk on by'. ${ }^{31}$ Shortly after, Lord Wallace of Tankerness, MP for the Liberal Democrats, took issue with the claim that accepting asylum seekers only encourages more people to make the difficult journey to Europe. This, he argued, 'was a bit like saying that the Good

\footnotetext{
25 Spencer, The Political Samaritan, p. 6.

26 Spencer, The Political Samaritan, p. 31.

27 Spencer, The Political Samaritan, p. 34.

28 The quotation is taken from Spencer and was part of Thatcher's 1968 Conservative Political Centre Lecture entitled 'What's wrong with politics?', see Spencer, The Political Samaritan, p. 55-56..

${ }^{29}$ Spencer devotes a section to 'The Labour Samaritan', see The Political Samaritan, p. 64-76.

${ }^{30}$ Spencer, The Political Samaritan, p. 76.

${ }^{31}$ Spencer, The Political Samaritan, p. 52.
} 
Samaritan should really have passed by on the other side because, by stopping to help, he was only encouraging more acts of highway robbery on the road between Jericho and Jerusalem' ${ }^{32}$

The Samaritan, and neighbourly love, thus have remarkable political currency in US and UK contexts, and are applied on a range of issues. In recent migration debates, the parable appears to be used particularly by those who argue for support of refugees and other migrants, and are critical of 'passing by on the other side'. With this in mind, we now turn to a detailed examination of the three cases from the recent migration debate in Europe, to see how this biblical theme is applied in the Netherlands, Norway and Germany.

\section{Who is the Neighbour? Exegesis and Politics}

4.1 The neighbour in the Dutch parliament

On December 4, 2018, the Dutch parliament debated the UN's Global Compact for Safe, Orderly and Regular Migration, the so-called Marrakesh immigration pact. ${ }^{33}$ The Rutte government intended to support the pact and State Secretary for Justice and Security, Mark Harbers (of the VVD, the People's Party for Freedom and Democracy), was invited to the lower house ahead of the UN conference on the pact, to be held in Marrakech, Morocco. The first speaker in the debate was Thierry Baudet, leader of the FvD, the Forum for Democracy.

While the FvD then and now only has two seats in parliament (out of 150), it became the largest political party in the provincial election, held on March 20, 2019. ${ }^{34}$ Criticism of current migration policies is one of the FvD's signature positions and it was not surprising, therefore, that Baudet, in his statement, took issue with the government's support of the Marrakesh pact. Baudet started off by giving his own motivations to enter politics. He described himself as being driven by the fact that he did not see any attempts 'to stand up for our values, for our culture, for our way of life, our freedoms.

\footnotetext{
${ }^{32}$ Spencer, The Political Samaritan, p. 52.

${ }^{33}$ See https://www.tweedekamer.nl/kamerstukken/plenaire_verslagen/kamer_in_het_kort/kamer-bespreektpact-van-marrakesh; https://www.un.org/en/conf/migration/.

${ }^{34}$ For the results, see https://www.verkiezingsuitslagen.nl/verkiezingen/detail/PS20190320.
} 
I saw how Islam settled in the Netherlands, and all the problems associated with it, with values and cultural viewpoints which are diametrically opposed to ours.' This is what he and his party intended to stop. Baudet then identified immigration as 'the biggest problem of our time', threatening 'our way of life, our culture and our freedoms'. Among the consequences of migration, Baudet listed aggression against women, intolerance towards gay people, Jews, and other minorities, pressure on social services, and terrorism. The list of problems, so Baudet, is 'inexhaustible'. The proposed pact would only contribute to these problems and to support it would therefore be 'irresponsible'.

Baudet constructed his appeal to 'our' values and freedoms in his parliamentary statement without any reference to Christianity, and as is the case for many other FvD policies. ${ }^{35}$ However, in less official communications Baudet describes himself as 'an agnostic cultural Christian', and suggests that Christianity has a role to play in reinventing the values necessary to combat 'Europe's identity crisis'. ${ }^{36}$ In a 2016 tweet, Baudet stated that Christians come in many different types: 'Catholics, Protestants, agnostics, atheists. All, in their own way, followers of Jesus'.$^{37}$

\subsubsection{Jesus in the Marrakesh debate}

Baudet referred to Jesus in the Marrakesh debate as well, not in his prepared remarks, but immediately afterwards, when challenged by Joel Voordewind of the Christian Union (CU). This Protestant Christian party combines socially conservative positions with a progressive stance on economic issues and immigration. ${ }^{38}$ Voordewind defended the pact and suggested that Baudet should not oppose it, since it was intended to make migration safer and more ordered, as outlined in article 13. This was a reason for Baudet to bring up neighbourly love, in the following verbal exchange:

\footnotetext{
${ }^{35}$ The FvD's 'Law Protection of Dutch Values', for example, does not refer to Christianity: https://forumvoordemocratie.nl/standpunten/wet-bnw.

${ }^{36} \mathrm{https} / / / c i p . n l / 60959-$-thierry-baudet-pleit-voor-herwaardering-christendom.

$37 \mathrm{https}: / /$ twitter.com/thierrybaudet/status/774691226415169536.

${ }^{38}$ The CU's political program can be found at https://www.christenunie.nl/.
} 
Baudet: 'Article 13 is another one of those eccentric articles that centres on the rights of migrants, rather than the rights of the local population in the countries where all those migrants go, with their culture and their convictions and after that with their family reunifications etcetera. That is what you should think about. Perhaps you think that Christianity is showing you the way, but Jesus actually talks about the neighbour: you should love your neighbour. You may love people far away, but not your neighbour. Your position is stone cold towards the Dutch people who have to deal with the painful, offensive consequences of the mass immigration that you encourage.'

Voordewind: 'This is interesting. When mister Baudet cites biblical examples, I will go along with him. Then I will ask you: who was that Good Samaritan? Was it the priest or the Levite?'

Baudet: 'I don't know about all that. I am standing up for the Netherlands. I am standing up for people in the Netherlands and I don't want mass immigration to continue...'

Speaker of the house: 'Mister Baudet ...'

Baudet: 'I am not interested in a pissing match about who knows the Bible better.'

Speaker of the house: 'Mister Voordewind has the floor.'

Voordewind: 'You make a comparison with the Bible. Then I tell you, it was the Good Samaritan, meaning, it was not one Jew helping another Jew, it was someone who was not from the people of Israel. That is what the story of the Good Samaritan is about: taking care of each other, yes, but the "each other" does not mean that, if they are outside of the Netherlands, we say: "just stay warm" .'39

Baudet did not respond to this exegesis and the discussion then returned to the pact itself.

39 The official transcript of the exchange can be found here: https://zoek.officielebekendmakingen.nl/h-tk20182019-31-48.html, see p. 8. 


\subsubsection{Baudet's Liberal Bible?}

What is striking about this brief exchange is that Baudet both introduces Jesus and the theme of the neighbour, and almost at the same time rejects a discussion about the biblical story when challenged about its meaning. He uses neighbourly love to criticise the attitude of a politician who explicitly identifies as Christian and therefore in Baudet's view apparently ought to be guided by the words of Jesus. Yet neighbourly love not only serves to attack Voordewind, it is also taken to support Baudet's own position that it is the Dutch population which deserves love, rather than migrants. By interpreting neighbour ('naaste') as the person who is geographically, culturally close, i.e., the Dutch, and contrasting this with people far away, to whom Jesus' instruction does not apply, Baudet can suggest that his position actually is the Christian one.

Yet Baudet's implicit reference to the Bible - what Jesus talks about - does not mean that knowledge of the biblical story is relevant to him. While Voordewind assumes he can join Baudet in drawing meaning from the story, and wants to go deeper into its plot, his questions about the characters in the story are not just left unanswered, but are completely rejected. Baudet mocks the idea that this is an appropriate way to deal with the Bible by making a rather vulgar comparison, suggesting that Voordewind's demonstration of knowledge is equal to a competition over who can pee the furthest ('een wedstrijdje ver plassen').

In this contradictory appeal to neighbourly love, claiming its moral status on the one hand while rejecting a more specific discussion of the biblical text on the other, Baudet appears to follow the pattern described above, as characteristic of the Liberal Bible. In its liberal form, the Bible's value is closely associated with Western culture, but its meaning is necessary vague, since non-Christians should not be alienated by its invocation. Baudet's possibly on-the-spot reference to neighbourly love and his immediate rejection of Voordewind's evidently superior knowledge of the text, suggest that he intuitively feels that the Bible constitutes attractive yet risky territory. 


\subsection{Norwegian neighbourly love}

Our second case comes from Norway, where in August of 2017, the broadcasting company NRK's radio program 'Politisk kvarter' ('Political Quarter') invited politicians Sylvi Listhaug of the Progress party (Frp), then Minister for Immigration and Integration, and Knut Arild Hareide, at the time leader of the Christian Democratic Party (KrF) to a debate about Norwegian and Christian values. ${ }^{40}$ Listhaug is a politician who identifies as Christian and explicitly mentions the importance of Christian values in her rhetoric. She explains in her biography Der andre tier (Where others stay silent) that although she disagrees with those who represent the Church of Norway on many issues, she has decided to remain a member of this church. ${ }^{41}$ Her stance on migration has provoked opposition from those who do not think it is compatible with being a Christian, as happens in the radio program discussed here. In the program, Listhaug defines neighbourly love as helping as many people as possible where they are, and not letting them into 'our' country.

\subsubsection{Values under pressure}

The theme of neighbourly love is introduced right at the start of the program, where Listhaug is criticised for not having a Christian understanding of what this love means. In response, Listhaug emphasises that Norwegian values are under pressure and that this will increase with higher immigration. She interprets neighbourly love in term of quantity: 'neighbourly love means for me helping as many of our fellow human beings as possible'. That is why she opposes an 'open door' policy which would bring as many people as possible to Norway. She argues instead that resources should be used in areas neighbouring war and conflict 'where millions of people live in desperation and without prospects for the future'.$^{42}$ Most important, she claims, is 'to help as many people as

\footnotetext{
40 The program can be found at https://radio.nrk.no/serie/politisk-kvarter/NREP37022917/09-08-2017._On the Norwegian context, see also Marianne Bjelland Kartzow, 'Guds Skaperverk Og Globalt Klasseskille: Fortellingen Om Hagar I Ødemarken', in Atle Sommerfeldt (ed.), Tro Til Handling: Sammen for En Rettferdig Verden (Oslo: Verbum, 2012).

41 Listhaug, Der andre tier, pp. 143-154.

42 Listhaug's original words are 'For meg så handler nestekjærlighet om å hjelpe flest mulig medmennesker. Ikke ha som mål å ta imot flest mulig her. Fordi jeg ønsker å bruke de store penger i nærområdene, til krig og konflikt,
} 
possible', and not fall victim to the 'tyranny of goodness' ('godhetstyranniet'), which suggests that you are a 'bad person if you want strict migration policies'. By opening our doors, Listhaug argues, we risk losing the values we take for granted, such as gender equality and freedom of speech. She mentions an encounter she recently had with an imam who supported stoning and the death penalty for blasphemy.

In the interview, Listhaug employs three complex terms with special connotations in the Norwegian immigration debate: neighbourly love ('nestekjærlighet'), fellow human beings ('medmennesker'), and neighbouring areas ('nærområdene'). Neighbourly love is vaguely associated with biblical narratives, and would probably be identified by most Norwegians as a Christian or broader religious concept. Fellow human beings will hardly have any specific religious connotation, while 'nærområde' would normally, outside of this discourse, work as a geographical term, which is not particularly value loaded, but here has echoes of the 'neighbour'.

\subsubsection{The paradox of neighbour: Quantity and quality of love}

What we can identify here, is a paradox of neighbourly love. Listhaug's solution is to help people in their neighbourhood of origin, and not let them be part of the Norwegian neighbourhood. Indirectly, by helping them (there), we help ourselves too (here). By keeping migrants in their neighbourhood, they are prevented from destroying our neighbourhoods. Listhaug seems to view this as a win-win situation, for both them and us. For them, this is good in terms of quantity (neighbourly love is to love as many people as possible), for us it is good in terms of the quality of our neighbourhoods (to keep our values).

In the name of love, the message is: neighbour, stay where you are and do not come to us. More neighbourly love is shown if more people are saved, far away. Accordingly, this type of neighbour love takes the neighbour primarily as metaphorical, and not as sharing space or being in proximity. They

der det sitter millioner av mennesker i desperasjon og uten framtidsutsikter.' https://radio.nrk.no/serie/politiskkvarter/NREP37022917/09-08-201 
are loved as long as they keep their distance and stay where they are, far away from our neighbourhood. In that way our neighbourhoods are kept intact, too. True neighbourly love is then to prevent strangers from becoming neighbours.

\subsubsection{Norwegian values as immigrants and museum artefacts}

Towards the end of the program, Listhaug is challenged by her opponent in the discussion, Knut Arild Hareide, who asserts that the Christian values she holds so dear are not particularly Norwegian, since they come from the Middle East. ${ }^{43}$ He seem to play with Norwegian-ness and with immigration from the Middle East of both values and people. Christian values, he suggests, immigrated to us via the biblical texts. Hareide laughs when saying this, to indicate how he ridicules Listhaug's concept of Norwegian values, since it builds on religious heritage from exactly the same region as the immigrants whose values she rejects.

Hareide further problematises Listhaug's use of these values by pointing out that they are not 'museum artefacts', which always remain the same, and challenges her to connect these values to all political issues. Listhaug replies that 'these values that you call museum artefacts, are the most important in the world to me', since they protect our freedom. History has shown that we need to protect our values, she argues, and we need people to put their foot down, 'to keep Norway as we know it'.

These two metaphors, (biblical) values as immigrants and museum artefacts, are intended by Hareide to characterize how bad Listhaug scores when it comes to neighbourly love. Firstly, by suggesting that the values she holds so dear are equally strange and trans-national as immigrants today. If she thinks she promotes and follows Norwegian values she is mistaken, since these values are shared and global. They even originate in the same neighbourhood as many immigrants knocking on European doors. These values have travelled across time and place, and to call them 'Norwegian' seems ignorant.

43 Hareide: 'Våre kristne verdier, ja, de kommer jo fra Midtøsten. Det er jo et paradoks.' https://radio.nrk.no/serie/politisk-kvarter/NREP37022917/09-08-201. 
The second metaphor, phrased as the accusation that she only treats these values as museum artefacts, also aims to downplay the influence these values have on her politics. Hareide imagines that Listhaug places these values on a pedestal and puts them up for display, in a way that is only rhetorical and lacks real impact. Her Christian values or neighbourly love statements are primarily symbolic, with no practical consequences. With the image of the museum, Hareide suggests that these values as artefacts remain on the shelf and are not put to practical use, as be believes they should.

These two points of criticism can be read as implicit comments on the Liberal Bible, which makes a similar move to equate Western liberal values with the presumed values of the Bible. Neighbourly love functions in this case as a stand-in for the Liberal Bible, since it is used in a flexible way to oppose the way of life of 'others' and support the society that is understood to be Christian. As noted above, the Liberal Bible is not applied in detailed and concrete ways, but remains necessarily vague, as Hareide suggests of Listhaug's neighbourly love.

\subsection{Neighbours and war refugees in German politics}

The final political appeal to the neighbour examined here comes from Germany, where Beatrix von Storch, member of the German parliament for Alternative für Deutschland, not only stresses the importance of neighbourly love, but also cites the full text of the parable from Luke. In contrast to the previous two cases, which were spoken references in parliamentary debate and in a radio program, this third occurs in a written source. It appears in the book Bekentnisse von Christen in der Alternative für Deutschland, a book of confessions by AfD members on what it means to be a Christian in this party, in the word of greeting (Grußwort) found at the beginning. ${ }^{44}$

The Alternative für Deutschland was initially formed, in 2013 , as a euro-sceptic party. ${ }^{45}$ It gradually shifted its focus from a single-issue party concerned with the European debt crisis, to a right-wing

\footnotetext{
${ }^{44}$ Beatrix von Storch, 'Grußwort von Beatrix van Storch, MdB', in Joachim Kuhs (ed.), Bekentnisse von Christen in der Alternative für Deutschland (Graz: Oxalis-Verlag), pp. 11-13.

${ }^{45}$ Robert Grimm, 'The rise of the German Eurosceptic party Alternative für Deutschland, between ordoliberal critique and popular anxiety', International Political Science Review 36/3 (2015), pp. 264-278.
} 
party campaigning particularly on themes connected to borders and immigration, such as the presumed dangers for German society posed by immigration and Islam. ${ }^{46}$ The party also thematises the 'traditional family', rejects marriage equality, and advocates the 'three-child family'. ${ }^{47}$ Early on, the Christian members of the party decided to come together in the Christen in der AfD, a group which aims to strengthen the Christian profile of the party. ${ }^{48}$ Beatrix von Storch is the current deputy leader of the Alternative für Deutschland and a representative in the German Bundestag, after having previously served as a member of the European parliament.

\subsubsection{The next-door neighbour and the stranger}

In her foreword to Bekenntnisse von Christen in der Alternative für Deutschland (Confessions of Christians in the Alternative für Deutschland) Von Storch explains why she, as a Christian, belongs to the AfD. She places great emphasis in her testimonial on neighbourly love: 'What counts for Christians in dealing with our fellow human beings is: love of the neighbour (Nächstenliebe), truth and justice' ${ }^{49}$ After describing the AfD as the only party which honours the family and especially protects unborn life, she continues with the theme of the neighbour:

'The AfD gives central importance to the commandment of neighbourly love [stellt sich dem Gebot der Nächstenliebe im Sinne des Gedanken]. Several Bible translations speak of the neighbour (Nachbarn). Not someone remote [der Fernste], not the stranger [der Fremde], not the other, but the person who is actually near. In addition, those who stand behind my/our neighbour can be lovingly cared for. But the instruction of neighbourly love is meant as

\footnotetext{
${ }^{46}$ Rüdiger Schmitt-Beck, 'The 'Alternative für Deutschland in the Electorate: Between Single-Issue and RightWing Populist Party', German Politics 26/1 (2017), pp. 124-148, 140

${ }^{47}$ Schmitt-Beck, 'The 'Alternative für Deutschland in the Electorate', p. 140.

${ }^{48}$ See the group's website https://www.chrafd.de/index.php/ueber-uns.

${ }^{49}$ Storch, 'Grußwort', p. 11.
} 
seriously as the commandment itself, and a government may not sacrifice its own people, to serve the stranger [den Fremden] under the banner of neighbourly love. That is wrong. ${ }^{50}$

Von Storch here moves from 'Nächstenliebe', which includes the rather abstract and biblical term 'Nächste', to 'der Nachbarn', the more everyday German word for the person living next door. She justifies this by observing that this term occurs in several Bible translations. ${ }^{51}$ Switching to this term allows Von Storch to emphasise the importance of closeness, 'the person who is actually near' and to further define the figure of the neighbour through its opposite: 'the stranger'. In this way, the attention shifts towards identifying who the object of the love and care should be, namely the person who is close rather than the person who is far. Like Baudet, Von Storch can thus argue that by improper application of this command, when it is used to serve 'the stranger', the government actually harms its 'own people'.

\subsubsection{The significance of a local inn}

After referring briefly to the importance of 'church marriage' (Ehe im kirchlichen Sinne) and the raising of children 'by mother and father' in the next paragraph, Von Storch then returns to the neighbour:

Since the autumn of 2015 the parable of the good Samaritan, Luke 10,25-37, appeals to me in a new way [spricht mich ... nochmal neu an]. I understand this parable as an argument for always helping war refugees close to their homeland. When the Samaritan found the victim of the

\footnotetext{
${ }^{50}$ Von Storch, 'Grußwort', p. 11.

51 It is unclear to which translations Von Storch refers here. The Einheitsübersetzung, which is the translation subsequently quoted, uses 'Nächste' in this passage to translate $\pi \lambda \eta \sigma i o v$, as do the Lutherbibel 1984 and 2017, Elberfelder Bibel, Menge-Bibel, Neue Evangelische Übersetzung, Neues Leben. Die Bibel, Schlachter Bibel and Zürcher Bibel. The alternative that occurs, mainly in more accessible translations, is 'Mitmensch', fellow human being, a term that does not have any connotations of proximity (this occurs in Basisbibel, Gute Nachricht Bibel, Hoffnung für Alle, and Neue Genfer Übersetzung). It is possible that Von Storch actually means English translations, and the 'Nachbarn' is her own translation of 'neighbour'.
} 
accident [Unfallopfer] on the street, he took care of the man and brought him locally to an inn to be looked after. He did not take him home with him to Samaria and let him bring his family. ${ }^{52}$

Von Storch presents a remarkable exegesis of the parable of the Good Samaritan, apparently inspired by the influx of refugees into Germany in $2015 .{ }^{53}$ The fact that the Samaritan did not take the victim home with him, or let him reunite with his family, but brought him to a local inn, is read as an argument for helping war refugees 'close to their homeland'. The parable is thus given a direct contemporary political application, and aspects of the story such as the location of the inn and the lack of reference to a family acquire significance in support of a particular policy with regard to 'war refugees'. An interesting detail in the wording is the fact that the victim is described specifically as an 'Unfallopfer', the victim of an accident, rather than a victim of violence, as the story suggests. This exegesis is followed by a quotation of Luke 10,25-37 in the Einheitsübersetzung, the official German translation of the Catholic Church, which does not use 'Nachbarn', but rather 'Nächste'. Von Storch does not comment on this and neither the parable, nor neighbourly love, are mentioned in what follows.

As already pointed out, Von Storch's interpretation is similar to the previous two in opposing the welfare of people far away with that of the national population. Like the other politicians discussed, Von Storch aims to discredit a particular understanding of neighbourly love by suggesting that it goes against those who are close. Since these physical neighbours have been identified as the true objects of neighbourly love, pointing out the harm they experience is not intended to merely correct the otherwise just impulse of taking care of strangers, but rather as showing such a policy to be a complete reversal of the biblical command.

There is a further interesting overlap with the application of neighbourly love by Sylvi Listhaug, who also argues in favour of taking care of refugees close to regions of conflict, rather than in Norway. While her argument does not make use of the parable in the way Von Storch's does, they both support

\footnotetext{
52 Von Storch' Grußwort', p. 11.

${ }^{53}$ For data on refugees in Germany, see https://www.unofluechtlingshilfe.de/fluechtlinge/faktencheck/.
} 
a particular policy with creative reference to the neighbour and ideas of closeness both geographically and culturally.

\section{Reflections: migration, neighbours and the Liberal Bible}

We will now extend the analysis already started in the discussion of the cases above, to see how the three cases connect neighbourly love to migration and to what extent their interpretation confirms the dominance of the Liberal Bible. Important to note is that the idea of neighbourly love as such is not rejected by any of the politicians, nor is its importance challenged in any way. Although Baudet refuses to go into a detailed exegesis of the Good Samaritan story, he is the one who brings up the words of Jesus on neighbourly love as a relevant principle. When Listhaug is probed on her commitment to neighbourly love, she does not question its pertinence, but defines it in a way that aligns it with her political agenda. All three thus accept that neighbourly love is something to strive for, most explicitly Von Storch, who takes 'love of the neighbour (Nächstenliebe)' to be one of the three things that count most for Christians, next to truth and justice. This confirms the observation from the context of US and UK politics, that the story has a broad appeal and can be applied to a range of issues and political objectives.

\subsection{Tensions between near and far}

As expected, given the profile of the politicians and their parties, the idea of neighbourly love is used in each of the three examples to oppose the acceptance of migrants into European countries. This common interpretation is arrived at in slightly different ways, yet in each case through using the potential ambivalence contained in the term 'neighbour', which is translated in both Dutch ('naaste'), Norwegian ('neste'), and German ('Nachbarn') with terms that suggest physical closeness. All three politicians make a distinction between near and far, and create opposition between places or people who are near and those who are far away. 
Baudet employs this opposition in its most extreme form, by suggesting that those who are near, the Dutch, are the rightful objects of neighbourly love, since they are closest geographically. A policy that welcomes migrants not only has the wrong object — since it benefits those who are far away rather than those who are nearby - it also hurts the Dutch, in Baudet's view, and can therefore be seen to violate the commandment to love one's neighbour. Accepting migrants is thus not only misconstrued neighbourly love, but even constitutes neighbourly harm.

Listhaug similarly suggests that the acceptance of migrants hurts the population of her own country. However, she understands neighbourly love in a much broader sense than Baudet, as aimed at 'our fellow human beings', with the goal of helping as many people as possible. It is not that those who want to flee war and conflict should not be helped, since Listhaug recognises that there are 'millions of people' who 'live in desperation and without prospects for the future', who apparently should count as neighbours in some sense. However, according to Listhaug, these people should be helped close to their originally location and not in Norway. In arguing for this, Listhaug uses love of the neighbour in two ways, creating something of a paradox, as noted above. Maximising the number of people who can be helped requires these 'neighbours' to stay far away, in areas that neighbour war and conflict, so that resources can go further than they would in Norway. Realising this neighbourly love at a distance is also a way of showing love to neighbours at home, who are protected from the challenge to Christian values that these far-away neighbours represent.

Von Storch combines the strategies of the other two, by making a case for helping 'war refugees close to their homeland', yet privileging those at home in Germany, as the true neighbours. Like Baudet, Von Storch argues that neighbourly love properly understood is directed not at those who are far away, at the stranger, or the other, but rather at those who are near, as the word 'Nachbarn' suggests. By bringing in this word, which does not occur in the translation she cites but apparently is found in other Bible translations - quite possibly in English - she can suggest that there is external support for understanding the term as referring to concrete physical closeness, rather than as a broader concept. 
Yet she interprets the parable of the Good Samaritan not in terms of the opposition between people who are near and far, as in her initial comments on neighbourly love, but rather by distinguishing between helping refugees 'close to their homeland', as opposed to taking them 'home', in this case letting them come to Germany. Her interpretation puts the focus not on the question who is the neighbour? which is asked in the text (10:29.36), but rather on how and where is love of the neighbour realised? to which the answer is understood to be: at a local inn, not back in Samaria. Von Storch's reading strategy thus highlights a particular aspect of the text that gains meaning in light of her question about the significance of near and far.

It is interesting to observe that this near-far distinction, which may draw on awareness of the English word 'neighbour', appears to be absent in political interpretations in English. While many creative readings of the parable occur, as we have seen, the idea that the true neighbour is next door, rather than far away, does not appear to feature and is certainly absent in the idea of 'passing by on the other side'.

\subsection{A Liberal Bible against migration}

To what extent can we see the uses of the Bible discussed here as drawing on the legacy of the Liberal Bible, which is characterised by general political-theological principles, rather than detailed textual agendas? In this respect, there appears to be a difference between Von Storch on the one hand and Baudet and Listhaug on the other. Von Storch does what Baudet explicitly rejects, namely looking more closely at a biblical text, rather than sticking with a general reference. She assumes that we can make a direct link between the Bible and politics, and argue for specific policies based on a particular element in the biblical text.

The vagueness and ambivalence of both Baudet and Listhaug seems to confirm the presence of a Liberal Bible behind their statements on neighbourly love and Christian values. In describing George W. Bush's Liberal Bible, Sherwood suggests that his vagueness is not necessarily due to lack of 
familiarity with the actual content of the Bible or the teachings of his favourite philosopher, Jesus. ${ }^{54} \mathrm{It}$ is rather a necessary characteristic of effectively using the Bible in a pluralistic context, both in relation to inner-Christian diversity and other religious affiliations, including the non-religious. In this context, so Sherwood, biblical texts cannot be specifically cited, but only invoked 'as the loose canopy of "Bible"' or presumably 'Jesus'. As part of this strategy, Bush invokes the Bible as a universal authority, while distancing himself from it in terms of divisive specifics..$^{55}$

The different contexts of the three cases may be relevant here. Baudet and Listhaug both speak for a general audience, in parliament and on national radio. They are both involved in discussion with politicians who identify explicitly as Christian, and they run the risk of being drawn into more divisive internally Christian specifics on the Bible, which could undermine their broader appeal. Getting involved in a debate on the Middle-Eastern origins of the Bible and how this might relate to values that Listhaug likes to present as both Norwegian and Christian, does not serve her agenda or profile, unlike that of her opponent. Similarly, Baudet has little to gain and much to lose by taking up the offer to do some serious biblical exegesis.

Von Storch, on the other hand, writes an opening greeting that is aimed at an internal audience. She speaks in a personal tone about her own religious orientation, addresses 'the brothers and sisters in ChrAfD' and signs off 'Your (Eure) Beatrix von Storch'. In this context, drawing on an understanding of the Bible that is more individual and more direct, rather than take it as the vague underpinning of the civil and national interest, is possible with less political risk.

As noted at the beginning, political scientists tend to see claims about Christian and biblical values made by politicians who oppose migration as exploitation and hijacking of religion and Christianity. Yet the cases discussed here show that they largely draw on a similar understanding of the Bible as found elsewhere in a political context, when it is seen as supporting liberal democracy, human rights, and freedom of the individual, all in a vague and unspecific manner. The politicians discussed here

\footnotetext{
54 Sherwood, 'Bush's Bible', p. 49.

55 Sherwood, 'Bush's Bible', p. 49.
} 
may have an application of the Bible that many scholars find undesirable, but that does not make their claims about the words of Jesus or about neighbourly love any more exploitative or insincere than those of others. They rather add new elements to the already wide range of readings, as outlined above. In the case of Baudet and Listhaug, they are in direct competition with the understanding of neighbourly love dominant in society and scholarship, represented by Joel Voordewind and Knut Arild Hareide, not coincidentally both representatives of traditional Christian parties.

\section{Concluding thoughts}

The case studies offered in this paper have hopefully shown the importance of examining references to the Bible in contemporary politics. Appeals to biblical themes and texts play a role in supporting political views today and are apparently credible and meaningful to part of the electorate. Scholars cannot simply dismiss these appeals as superficial or instrumental, just because the views in question or the people who advance them, do not conform to their ideas of what is legitimately Christian. These references ought to be examined in their own right, as evidence for the role of the Bible in contemporary political and cultural thought. The relevance of the concept of the Liberal Bible has been confirmed here, and can inform further efforts to examine similar material.

Much more work is to be done to see how interpretations of the Bible, as a symbol, or a source for specific ideas and texts, functions in these new constructions of European identity that is built on hostility towards migrants and Islam. It is interesting given this polemical objective, that Islam contains a strong tradition focussed on love of the neighbour, which is sometimes seen as a fruitful point of contact between Muslims and Christians. ${ }^{56}$ The Qur'an contains a command to do good to various

\footnotetext{
${ }^{56}$ In their open letter to the world's Christian leaders in 2007, titled 'A common word between us and you', 136 Muslim leaders and intellectuals proposed 'love of the One God, and love of the neighbour' as the 'foundational principles' for peace and understanding between Muslims and Christians. 'These principles are found over and over again in the sacred texts of Islam and Christianity. The Unity of God, the necessity of love for Him, and the necessity of love of the neighbour is thus the common ground between Islam and Christianity.' (see https://www.acommonword.com/the-acw-document/; Oddbjørn Leirvik, 'Aw qa'la: 'Li-ja'rihi': Some Observations on Brotherhood and Neighborly Love in Islamic Tradition', Islam and Christian-Muslim Relations 21/4 (2010), pp. 357-372, 357).
} 
groups of people and refers to different kinds of neighbours, somewhat along the lines suggested in the cases discussed above: 'to parents do good, and to relatives, orphans, the needy, the near neighbor, the neighbor farther away' (Q 4.36). ${ }^{57}$ This distinction is interpreted in different ways in Islamic tradition, suggesting obligations between people who differ on physical kinship, religious difference and local proximity. ${ }^{58}$ Our point here is of course not to glibly suggest that Islam gets something right that these Christian politicians get wrong. It is rather that using texts about neighbours to think about who owes what to whom, and how geographic and cultural distance figures into this, is common to both Muslim and Christian tradition, even if the Bible can be used polemically to suggest that there is something essentially different about European neighbourly love.

57 Translation The Noble Qur'an, available at https://quran.com/4.

58 See Leirvik, 'Aw qāla: 'Li-jārihi', pp. 260-367. 